\title{
ORVOSTÖRTÉNET
}

A Szentendre Egészségügyi Intézményei Kiemelt Rendelőintézet Traumatológiai Szakrendelés közleménye

\section{0 éve mutatták be a magyar orvosok által feltalált „Új typusú tábori Röntgen-automobilt”}

\author{
DR. NEMES GYÖRGY
}

\section{ÖSSZEFOGLALÁS}

Egy elfelejtett, később világszerte elterjedt, magyar orvosok által alkotott, napjainkban éppen száz éves „találmány”, „,hungarikum” „Új typusú tábori Röntgen-automobil” létrejöttének előzményeit, körülményeit, érdekes megvalósítását ismerteti a szerző, amely a hadisebészet és traumatológia történetének szempontjából is rendkívüli. Bár évszázadokon át a hadisebészek törekedtek a sebesültek ellátására, ez folyamatosan fejlődött is, ezt akadályozta az érzéstelenítés és az emberi testbe való „belelátás” hiánya. Az I. világháború idején kiderült, a sebesültek ellátása nem megvalósítható röntgenezés nélkül. Lorenz Böhler kijelentette, a csontok és ízületek lövési sérüléseinek ellátásához szakosított kórházak, gyakorlott orvosok, megfelelő eszközök és hordozható röntgengépekre van szükség. Az I. balkáni háború idején - 1912-13ban - a Magyar Vöröskeresztnek még röntgenkészülék nélküli kórháza volt Szófiában. A Budapesti Sebészeti Klinika professzorának Dollingernek közvetítésével felkérték Gergő és Szöllősy tanársegédeket e hiány megoldásának kidolgozásával. Ők az akkor kapható legjobb röntgenkészüléket ráépítették egy Opel teherautóra és számos máig használt újítást, innovációt is alkalmaztak, amelyet a Magyar Sebésztársaság Nagy-gyúlésén 1913 májusában bemutattak, majd 1914 áprilisában, az Orvosi Hetilapban is ismertették. Az I. Világháború idején ennek nyomán többszáz hasonló készült a sérültellátó helyek számára, ezzel sok ezer katona élete volt megmenthető.

\section{Kulcsszavak: $\quad$ Háborús sérülések; Röntgendiagnosztika; Orvostörténet;}

Gy. Nemes: An invention by Hungarian surgeons introduced hundred years ago: "New type field Röntgen-Van"

The author reveals the history and the circumstances that lead to the creation of a forgotten Hungarian invention which just turned a hundred years old, the field $X$-Ray machine, which is exceptionally interesting from the point of the history of both military surgery and traumatology. Though military surgeons did their best to treat casualties, improvements were hindered by lack of anaesthesia and insight into how human bodies worked. From the World War One, it was obvious that treatment of casualties was not possible without X-raying. As stated by Lorenz Böhler, treatment of gunshot injuries of bones and joints required specialised hospitals, experienced doctors, the right kind of equipments and portable $X$-ray machines. During the First Balkan War in 1912-13, the Hungarian Red Cross had a hospital in Sofia without X-ray machines. With the assistance of Dollinger, Professor of the Budapest Department of Surgery, Gergó and Szöllösi assistant lecturers (senior registars), were appointed to work out a solution. They attached the best X-ray machines at the time to an Opel truck. They put other improvements and innovations to use, which then they introduced first in 1913 at the meeting of the Hungarian Surgical Society, then in April 1914 in the Hungarian Medical Journal. This was followed by the manufacturing of hundreds of similar devices during the World War One, saving the lives of thousands of soldiers.

Key words: $\quad$ History, 20th Century; Military medicine - History; Radiology - History; Wounds and injuries - Diagnosis/History; 
A balesetsebészek, de az orvostörténészek számára is közismert, hogy a vadászat, háborúk egyre előbbre vitték a sérülések kezelését. Két nagyon fontos, a gyógyításban nélkülözhetetlen, a jelen balesetsebésze számára mindennapos alapmódszer és diagnosztikai eszköz hiánya behatárolta és a fejlődést megállította, a medicina történetében forradalmi tényező: az érzéstelenítés és az emberi testbe történő „betekintés” lehetőségének hiánya. E kettő az I. Világháború előtt megoldódott, utat nyitva a traumatológia azóta is tartó egyre gyorsuló, beláthatatlan végű haladásának (8).

A 15 millió ember életét követelő I. világháború négy éve alatt új gyilkoló eszközök jelentek meg a hadviselésben: sorozatlövő fegyverek, tankok, repülőgépek. Ez a változás új sérüléseket és a sebesültek számának gyors növekedését hozta, kikényszerítve a hadisebészet és a sérültek mentésének, beszállításának gyors fejlődését. Az eredményes kezelés egyik alapkérdése, hogy mennyi idő kell a szakorvosi ellátáshoz jutásig. Gépesítés még alig volt, a mentéshez, szállításhoz lovakat, szekereket használtak ez 20-25 kilométert, 4-5 órás utat is jelentett.

A „nagy háború” első éveiben sok sérülést nem tudtak a régi módszerekkel sikeresen gyógyítani, amelyek kezelése később rutinná vált. A gyógyítást nehezítette az is, hogy bizonyos eszközök csak a szakosított frontvonal mögé települt hadikórházakban álltak az orvosok rendelkezésére (4). 1895-ben Wilhelm Conrad Röntgen felfedezésének köszönhetően már ismerték a röntgensugárzás orvosi alkalmazását (9), a képeket azonban csak e kórházakban tudták elkészíteni elsősorban a szükséges villanyáram hiánya miatt. A súlyos koponya, mellkas és hasüregi sérültek a helyszínen vagy szállítás közben meghaltak, az élve beérkezettek 63\%-ának végtagsérülése volt, ezek negyedrésze érintette a csontokat és ízületeket. Utóbbiak eredményes kezeléséhez a röntgen nélkülözhetetlen volt, mert másképp a későbbi hadirokkantak 81\%-a közülük került ki (10).

Lorenz Böhler szerint - akinek a spanyol polgárháború idejéből már voltak háborús tapasztalatai - a csontok és ízületek lövési sérüléseinek ellátásához szakosított kórházakra, gyakorlott orvosokra, megfelelő eszközökre és hordozható vagy telepíthető röntgengépekre van szükség (2).

Érdemes és érdekes vázlatosan visszatekinteni a háborús sérülések ellátásának történetére. $A$ világ legrégebbi sebészeti témájú „szakkönyve” az Edwin Smith-papirusz ókori egyiptomi, a sérülések sebészeti kezeléséről szóló írás bizonyítja azt is, hogy a csatatéri sérülések gyógyítása anatómiai megfigyeléseken és tapasztalatokon alapult. Az írás valószínúleg Imhoteptől származik, aki pap, építész és orvos volt Kr. e. 3000-2500 körül. A ma is alkalmazott háromszintű sérülésellátás (triage) alapjait is megtaláljuk benne: három csoportba sorolták a sérülteket: kezelhető, esetleg meggyógyítható, menthetetlen vagy kezelhetetlen (3).

A csatatereken a sebesülteket magukra hagyták, így azok is meghaltak elvérzésben, sokkban, kiszáradásban, akiknek egy része megmenthető lett volna a korabeli eszközökkel is. A hadi orvoslás folyamatos, kényszerű nagy átalakulásokon ment át. A XV-XVI. században megjelentek a lőtt sebek, ez új feladat elé állította a sebészeket, kutaszolással, a lőcsatorna, vagy seb feltárásával, magfogó-szerű eszközökkel, próbálták megkeresni és eltávolítani a testben maradt lövedékeket érzéstelenítés nélkül, „,vakon”, gyakran sikertelenül, írta Hans von Gersdorf, „Tábori könyv a seborvoslásról” című könyvében (10). Az amputáció volt az egyetlen hatékony eljárás a sebfertőzések megelőzésére és az élet megmentésére. Jean Dominique de Larrey Napoleon vezető hadisebésze 1812-ben, a borogyinói csatában és a visszavonulás során tapasztalta, hogy a fagyott végtagok, kiízesítése fájdalmatlan (kis, főleg bőrön lévő elváltozások eltávolítását ma is végezhetjük fagyasztásban). Képes volt egy percen belül elvégezni egy végtag amputációt, ami önmagában is fontos volt a beteg szenvedéseinek rövidítésében és a traumás és mútéti sokk kialakulásának csökkentésében.

Morton első éternarkózisa 1846 szeptemberében történt. Ez elindította fájdalom nélküli mútétek többé véget nem érő sorozatát. Már 1847. január elején Balassa éternarkózisban operált, nem közismert, de tény, hogy a medicina e vívmányának alkalmazásával Magyarország megelőzte a legtöbb európai államot. Bécsben Schuh első mútétjét csak 1847. január 27-én (más adat szerint február 27-én) végezte éteraltatásban. Tábori körülmények között 1855-ben a Krími háború idején Pirogov operált először az orvos- és a traumatológia történetében éternarkózisban. Pirogov az 
angol-francia csapatok által ostromolt Szevasztopolban volt fősebész, de ő használt először gipszkötést is, így a sérült végtagok kezelése sikeresebb volt és sok katonát mentett meg a rettegett amputációtól. Szinte groteszk, hogy a másik oldalon a Selimiye hadikórházban 1854-ben dolgozott a női betegápolás megalapítója, az orvostörténelem egy másik kiemelkedő legendás alakja, Florence Nightingale, a „Krími angyal”. Ő, 34 ápolónő társával, önfeláldozó munkájukkal a kórházi halálozást 2/3-dal csökkentette. Május 12-én, születésének napján van az Ápolók Világnapja (1).

A traumatológia haladásának egyik feltétele az érzéstelenítés tehát megoldódott. A másik nélkülözhetetlen eszköz az „emberi testbe való belelátás” is már igen közeli, pár évtized távolságban volt csak. Ehhez a tudomány és technika bizonyos fejlettségére, például elektromos áramra volt szükség. A würzburgi Orvos-fizikai Társaság lapjában, 1895-ben megjelent Conrad Wilhelm Röntgen beszámolója egy újfajta sugárról, amely áthatol a szilárd testeken és láthatóvá teszi az addig közvetlenül nem érzékelhető belső szerkezeteket. Ő X-sugárzásnak nevezte el, Angliában, az orvosi nyelvben ma is így használják: „X-ray” (9). 1896-tól már az orvosi diagnosztika legfontosabb eszköze lett: vitatott első alkalmazására a londoni Guy-kórházban került sor, amikor egy matróz csigolyái közé beékelt késpengét tettek „láthatóvá”.

1896. január 16-án a Pester Lloyd leközölte Röntgen írását, ezen a napon, a budapesti Matematikai és Fizikai Társulatban a felfedezést ismertették és bemutatták azt a felvételt, amelyet Eötvös Loránd készített saját kezéről. Január 18-án a Királyi Orvos Egyesületben Hőgyes Endre „Csontvázfotografálás testen keresztül Röntgen szerint" címú előadása már az orvosi alkalmazást vázolta fel, kiemelve fontosságát a csonttöréseknél. 1898. február 8-án Dollinger Gyula professzor - kinek jelentős szerepe lesz a mozgó röntgen-automobil megszületésében - a „Röntgenfényképezéssel a tenyérben meglelt golyó esete” címmel betegbemutatót tartott. Röntgenfelvétel alapján sörétet távolított el tenyérből (ennek a mútétnek az időpontja körülbelül két hónappal megelőzte a már említett londoni sebészi alkalmazást(!). A prioritás tehát itt is magyar volt, ez azt is bizonyítja, hogy Budapesten milyen gyorsan reagáltak a korszakalkotó felfedezésekre!

A Vöröskereszt Nemzetközi Bizottsága 1882. január 20-án jelentette be a Magyar Vöröskereszt megalakulását gróf Károlyi Gyula elnökletével. Az I. Balkáni Háborúban 1912-1913-ban már kirendeltségük és kórházuk volt Szófiában. Jelentésükből kiderült, hogy a tábori kórház múködése hiányos röntgenberendezés nélkül, mert a végtagsérülések így megfelelően nem kezelhetők. E jelentés alapján, Babarczi-Schwartzer Ottó dr. a Vöröskereszt főgondnoka tárgyalt Dollinger Gyula egyetemi tanárral és megbízták Gergő Imre és Szölőssy Lajos tanársegédeket a kórházak és segélyhelyek telepíthető röntgenkészülékkel való ellátásának megoldásával (7). Gergő doktor - kinek később számos találmánya volt - javasolta, hogy a „Röntgen laboratórium egy megfelelő automobilban legyen elhelyezve és annak benzinmotorja egyúttal, mint villamosságfejlesztő központ szerepeljen - tudomásunk szerint ilyen berendezést eddig sehol nem szerkesztettek..." (6). A gondolatot a megbízók elfogadták, bár nem tudhatták, hogy milyen fontos, döntést hoztak, a rövidesen elkezdődő I. Világháború sebesültjei szempontjából!

1913-ban a feladat szokatlan, teljesen új és követhető példa nélküli volt, amit kitűnően és a mai napig időt állóan oldottak meg. Valamennyi megoldásukat a mai röntgenbuszokban, modernizált kivitelben alkalmazzák. Az egyedileg kialakított két helységből álló speciális karosszériát egy 30 lóerős Opel Chassis teherautóvázra építették rá, ami 2000 kiló terheléssel 24-30 kilométer/óra sebességgel tudott haladni. A „chuffeur” ülés az akkori szokásoknak megfelelően nyitott volt, az ülés alá építették be az áramfejlesztő dinamót, amelyet egy kar segítségével lehetett közvetlenül rákapcsolni az autó motorjára. Ilyen megoldást a világon addig sehol nem alkalmaztak. A felépítmény 3.0×1.45 alapterületű, belmagassága 1.7 méter volt és két részre osztották. Az első kisebb, külön bejáratú rész volt a sötétkamra, vörös fénnyel, szellőzéssel. Itt helyezték el az előhíváshoz, fixáláshoz, mosáshoz szükséges medencéket, volt egy 58 literes víztartály is a karosszéria felső első részében. Az előhívó pult íróasztallá volt alakítható, lenyitható ülőkével. A rázkódásra érzékeny röntgencsöveket külön rugózással ellátott tartóban szállították, por ellen vitorlavászon huzatban. Az erős védőtokra azért is szükség volt, mert ezek a csövek robbanásveszélyesek voltak így a szilánkok nem röpülhettek szét. A sugárérzékeny filmeknek ólomfalú farekeszeket készítettek. A karosszéria végén a kétszárnyú ajtó a nagyobb részbe a tulajdonképpeni röntgen-helyiségbe nyílt, 
itt volt az alapkészülék, annak motorja, transzformátora és tároló szekrények. A fektetőt felvételek készítésére és átvilágításra is alkalmassá tették. Ide tolták be a sebesültet, és mivel a háborús viszonyokat is figyelembe vették, szükség esetén egy sérültet fekve is lehetett ezen szállítani. Ha a röntgenkészüléket épületbe telepítették, akkor a felszereléshez tartozott egy 50 méteres kábel is a termelt áram szállítására. A tetőn összehajtva egy lenyitható és elsötétíthető sátor volt, ami felállítva növelte a röntgenezéshez szükséges fedett területet. Ennek könnyebb eléréséhez a karosszériára kétoldalt lehajtható lépcsőt, létrát is elhelyeztek (1. $a-c$ ábra). Az akkori idők legmodernebb „Ideal” röntgenfelszerelését a bajorországi Reininger, Gebbert és Schall Rt. gyártotta, amelynek magyarországi szervize is volt.

A gépkocsi mozgékonysága lehetővé tette, hogy még nagyobb hadmúveleti területen is több tábori kórház együttes szükségletét ellássa. A különleges egyedi karosszéria kialakítását Kölber Jenő császári és királyi kocsi gyáros üzemében készítették el. A költségeket a csepeli Weisz Manfred vállalta. A jármú élethű makettje, eredeti dokumentációja, megtekinthető a szombathelyi Smidt múzeumban (7) (2. ábra).

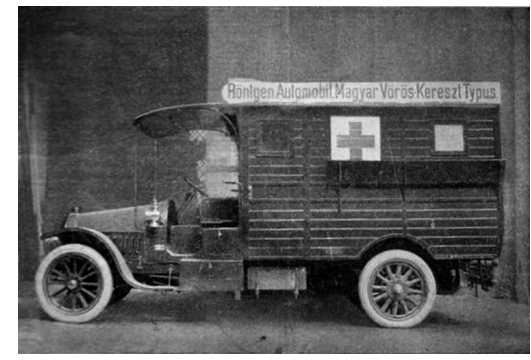

$1 a$

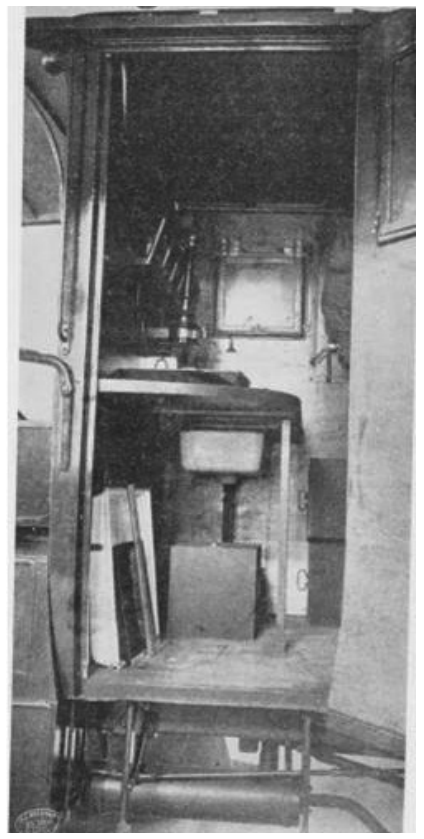

1c

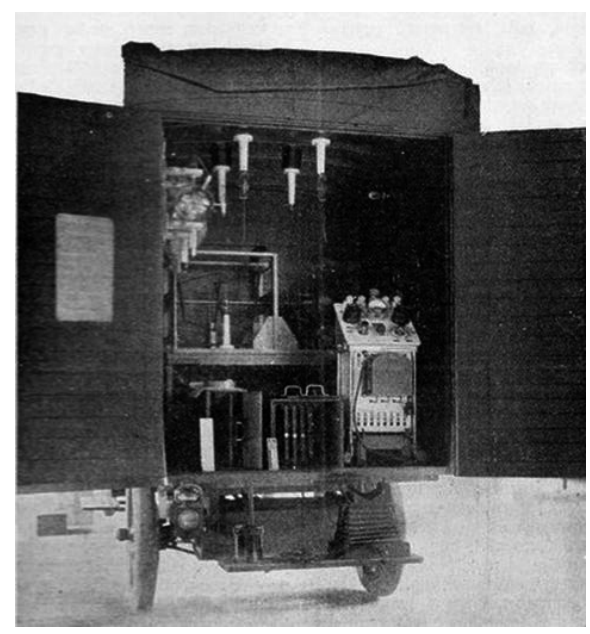

$1 b$

\section{1. ábra}

a) A röntgen-automobil oldalnézetböl

b). a belseje

c). a sötétkamra

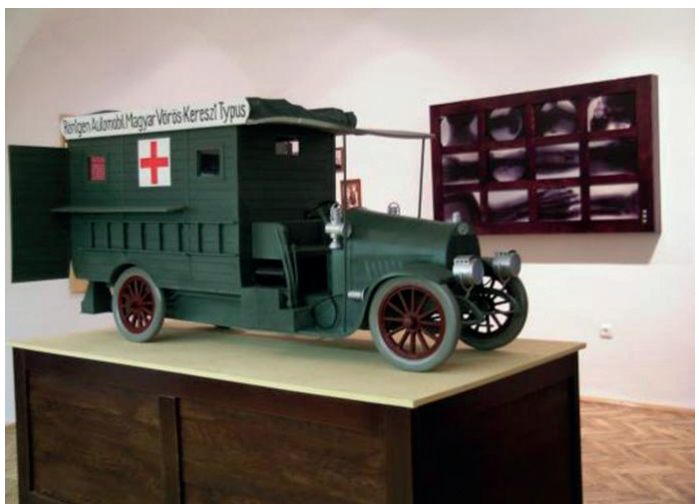

2. ábra

A Gergő doktor által készített makett 
Dr. Gergő Imre tanársegéd, későbbi fötörzsorvos, a „Röntgen-automobilt” a Magyar Sebésztársaság Nagy-gyúlésén 1913 májusában bemutatta, majd 1914 áprilisában az Orvosi Hetilapban is ismertette (idézve eredeti megfogalmazásában):

„Uj typusú tábori Röntgen-automobil.*” „Írta: Gergő Imre dr., egyetemi magántanár, tanársegéd. Közlés a budapesti kir. magy. tud.-egyet. I. számú sebészeti klinikájáról. (Igazgató: Dollinger Gyula dr. m. kir. udv. tanácsos, egyetemi nyilv. rendes tanár.) *Ezen Röntgen-automobilt a Magyar Sebésztársaság VI. nagy-gyúlésén 1913 május 23.-án is bemutattam." (5).

Idézem újításaik (ma innovációnak hívnánk) összefoglalását, az ő leírása szerint:

1. Az autó motorjának sajátos összeköttetése a dynamóval új elképzelés.

2. Karosszériába beépített sötétkamra,

3. Ideal röntgen készülék alkalmazása,

4. Érkezés után azonnal üzemképes.

5. A készülék pár perc alatt az autón kívül is használható a kábel révén.

6. Ha van más áramforrás, a motor és dynamó pihenhet, a sötétkamra használható.

7. Átvilágításra is alkalmas a rtg. helyiség, mert a gyorsan felállítható sátor csatlakozik a jármú belsejéhez, míg a röntgen berendezés a kocsiban maradhat.

8. A 7.-es pontban említett célra szétszedhető új szerkezetű az autóhoz csatlakozó elsötétíthető sátort alkalmaztak, amelybe „fénysugarak „, kívülről be nem juthattak.

9. A segédeszközök elhelyezése, rögzítése speciális megoldása.

10. Újítás a Röntgen lámpák védelme rázás ellen.

Megjegyzi még: béke idején a röntgen berendezés az autóból kiszerelhető, telepített röntgen laboratóriummá alakítható.

„A legfőbb újítás az egész készülék alapgondolata. Úgy hiszem orvosi humánus szellemünk is megkívánja, hogy a modern kor tökéletes gyilkoló fegyvereit a legtökéletesebb egészségügyi felszereléssel paralyzáljuk."

Akkor még senki nem sejtette, hogy pár hónap múlva kitör az I. világháború, 1914. július 28-án a Monarchia hadat üzent Szerbiának, a szövetségi szerződés értelmében egész Európa hadba lépett. A mozgó Röntgen-autók használata az I. világháborúban gyorsan terjedt, sok tízezer katona életének megmentését segítették. A hadseregek szakosított kórházainak egy részében a háború kezdetekor is már telepített röntgenek voltak, de a fronthoz közeli kórházakban, nagyobb elsősegélynyújtó helyeken nem (3. ábra).

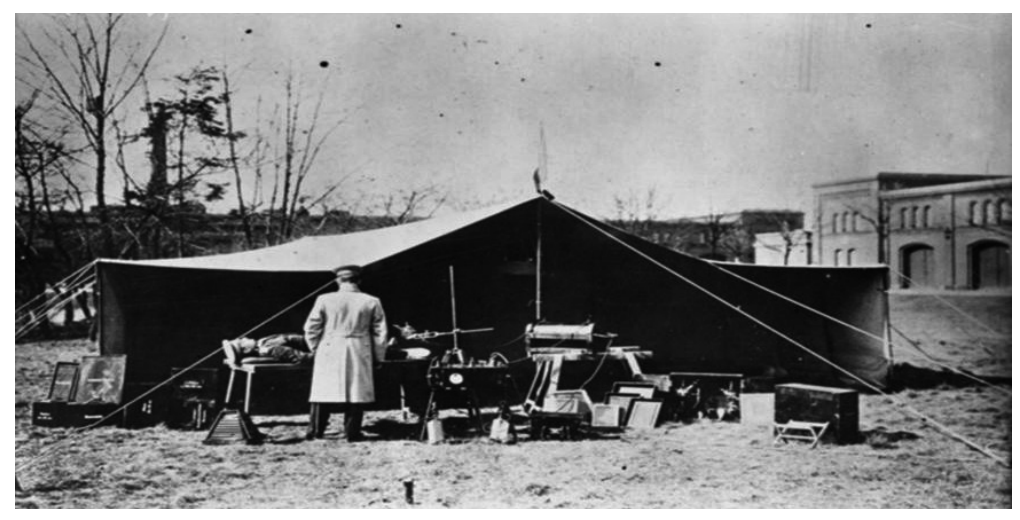

3. ábra

A német hadsereg szabadtéri röntgengépe 
Sajnos a máig megszokott magyar tétovázás, a találmány használhatóságának helytelen felmérése komoly akadályt jelentett: Gergő doktor katonaorvosként szolgált az első világháborúban, a sors fintoraként azonban a maga fejlesztette röntgenautót soha nem használhatta a fronton, mivel annak rendszeresítésére nem került sor. A Hadügyminisztérium 14. osztálya foglalkozott a haderő egészségügyével, így az orvosi műszerek felszerelések, technikai újítások témáiban is illetékes volt. Az osztály 1914. évi névmutatójában ma is megtalálható az autó, illetve a készülék leírása, amely arra utal, hogy a bevezethetőségét mérlegelték. Mégis úgy tűnik, a haderő nem tudta (talán anyagi okok miatt) vagy nem akarta Gergő ezredorvos úr (4. ábra) újítását rendszeresíteni, azt sorozatban legyártani (7). Ennek ellenére 1914-ben a propaganda ízú budapesti Hadikiállításon is ott volt az egészségügyi szekcióban a Röntgenautomobil, Gergő doktor nevével (5. ábra).

Nem úgy Franciaországban. Igaz ott sem a hadsereg kezdeményezte, hanem Madame Marie és Pierre Curie nevéhez fúződik. Hazaszeretetből kezdték szorgalmazni a röntgenautó felépítését és használatát 1915-ben, mert ők is azt tapasztalták, hogy a hadikórházakban csaknem teljesen hiányoznak a röntgenberendezések. A Katonai Egészségügyi Szolgálat csak egy-két nagyvárosban biztosított néhányat, mert használatukat fényűzésnek vélte! Ennek köszönhetően saját költségükön először egy kis teherautót alakítottak át és szereltek fel mozgó röntgenlaborrá, ezt további húsz követte. Madame Curie letette az autóvezetői vizsgát is és az egyiket maga vezette (6. ábra). A marne-i csata sérültjeit ő maga röntgenezte meg. Valószínű 1915-ben felhasználta a magyar találmányt, mert miután az 1913. május 23-án ülésező Magyar Sebésztársaság 6. Nagygyűlésén Gergő doktor bemutatta az új konstrukciót és az Orvosi Hetilap 1914/14. számában ismertette, ennek magyar és német nyelvű szövegét megküldték minden ország Vöröskereszt Egyletének.

Magyarország később is, a II. világháború utáni években is élen járt a mozgó röntgenautók gyártásában, de megváltozott feladattal. A belső kialakítás korszerűbb, de lényegében minden elemében azonos az éppen 100 éve magyar orvosok által kigondolt „Röntgen automobillal”! Ebben annak is kényszerítő szerepe volt, hogy a tüdőtuberkulózis igen elterjedt volt nálunk, hiszen ", magyar betegségnek" is hívták, és a diagnózishoz az eldugott kis falukban is szükséges volt a röntgenszürés. Ezek a buszok ma sem nélkülözhetők. Az Ikarus korszerű büszkesége, a Máltai Szeretetszolgálatnak készített E 134. jelű tüdőszűrő busz (7. ábra).

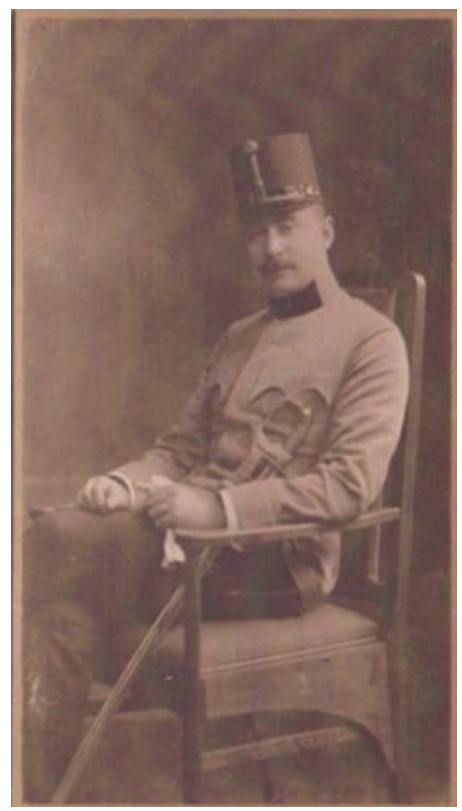

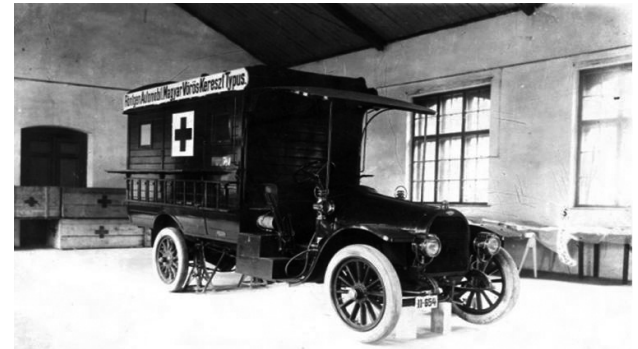

5. ábra

Az eredeti röntgen automobil a hadi kiállitáson az egészségügyi szekcióban

4. ábra

Dr. Gergö Imre ezredorvos 


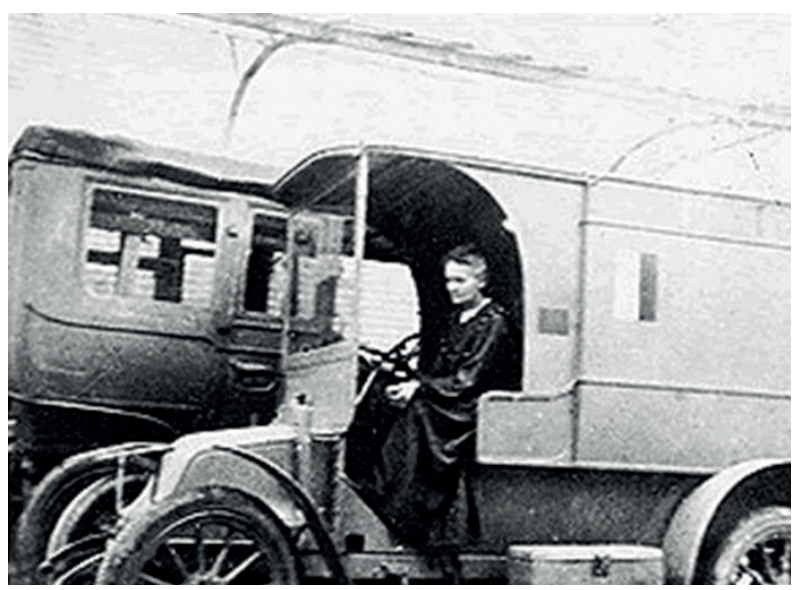

6. ábra

Marie Curie röntgenautóján a „kis Curie”-ben

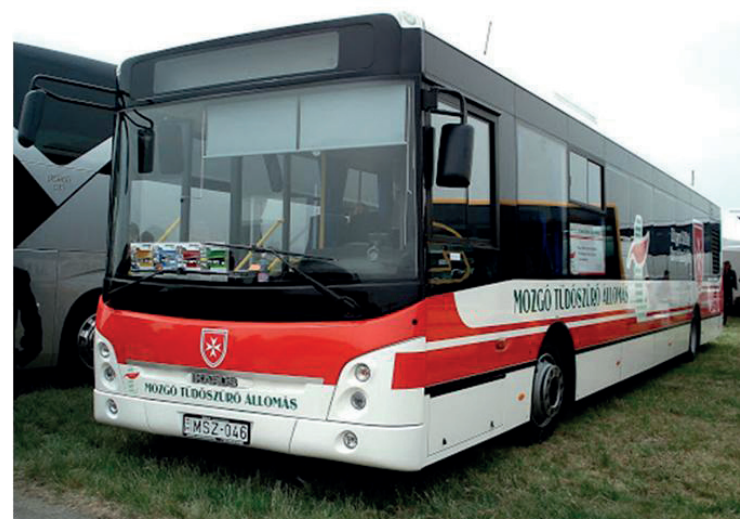

7. ábra

Ikarus E 134 röntgenbusz 


\section{IRODALOM}

1. Biography.com Editors: Florence Nightingale Biography. Hozzáférhetö 2016-10-24 http://www.biography.com/people/florence-nightingale-9423539

2. Böhler L.: Die Technik der Knochenbruchbehandlung. 14. Aufl. Wien, Verlag Wilhelm M. 1951.

3. Breasted J. H.: The Edwin Smith Papyrus. New York Historical Society Quarterly Bulletin, 1922. 6. 1. 5-31.

4. Franz C.: Lehrbuch der Kriegschirurgie. 1-4. Aufl. Berlin, Springer, 1919-1944.

5. Gergő I.: „Uj typusú tábori Röntgen-automobil”. Orvosi Hetilap, 1914. 58. (14): 272-275.

6. Keppel Cs.: A körmendi Grünbaum család háromgenerációs orvosi pályája. In: Ihász István, Pintér János (Szerk.): Történeti Muzeológiai Szemle. Az MMTT Évkönyve. 8. II. Bp. 2008. 187-197. p.

7. Keppel Cs.: A szombathelyi Smidt Múzeum első világháborús legérdekesebb emlékei. In: Bedécs Gy. et al.: Az első világháború emlékeztetöi Pozsony vármegyétöl a Muravidékig. Györ, Universitas-Györ Nonprofit Kft. 2009. 187-195. p.

8. Nemes Gy., Keppel Cs.: Magyar orvosok tervezte, elfelejtett innováció: „Uj typusú tábori Röntgen-automobil” 1913. május. A Magyar Ortopéd Társaság és a Magyar Traumatológus Társaság 2015. évi Közös Kongresszusa. Sárvár, 2015. Június 13. Előadás.

9. Röntgen C. W.: Über eine neue Art von Strahlen. Würzburg. 1895.

10. von Gersdorff H.: Feldbuch der Wundartzney = Tábori könyv a seborvoslásról. Darmstadt: Wissenschaftliche Buchgesellschaft, 1967. Reprint of the 1517 edition.

Prof. Dr. Nemes György

2000 Szentendre, Szamóca u. 13.

E mail: drnemesga@t-online.hu 